Reprod. Nutr. Dévelop., 1986, 26 (2 B), 717-728.

\title{
Effect of soya protein on digestive enzymes, gut hormone and anti-soya antibody plasma levels in the preruminant calf
}

\author{
P. GUILloteAU, T. CORRING $(*)$, J. A. CHAYVIALLE $(* *)$, C. BERNARD $(* *)$, \\ J. W. SISSONS $\left(^{* *}\right)$, R. TOULLEC
}

with the technical assistance of Marguerite BEAUFILS, Mireilie CONNAN, Anne-Marie GUEUGNEAU $\left(^{*}\right)$, Monique LESNE, J. N. NOUCHET, H. E. PEDERSEN ${ }^{* *}$ ) and Sheila M. THURSTON (***).

Laboratoire du Jeune Ruminant, I.N.R.A. 65, rue de St-Brieuc, 35042 Rennes cedex, France.

${ }^{*}$ ) Laboratoire de Physiologie de la Nutrition, I.N.R.A., 78350 Jouy-en-Josas, France.

(**) Unité de Recherches de Physiopathologie digestive, INSERM, Hôpital Edouard Herriot, 69374 Lyon cedex, France.

(**) Animal and Grassland Research Institute, Shinfield, Reading RG2 9AQ, England.

Summary. The effect of a milk substitute diet containing concentrated soya protein on secretory functions of the abomasum and pancreas and on plasma concentrations of gut hormones and soya antibodies was studied. Sixteen calves aged 12-19 weeks were given a milk substitute in which a major part of the protein source was either soya concentrate (soya diet) or skim milk (control diet). The soya diet was prepared by hot aqueous ethanol extraction of soyabean meal to remove oligosaccharides and inactivate antigenic constituents.

Circulatory $\lg G$ antibodies against soya proteins were found in all of the calves when they were 16 weeks of age. Their titres increased slightly between 16 and 19 weeks, irrespective of the diet. It seems unlikely that the presence of these antibodies was related specifically to the feeding of the soya concentrate.

At slaughter the weight of the gastric mucosa and pancreas and quantities of pancreatic protein together with specific activities of trypsin and chymotrypsin were significantly lower $(17,20,16,30$ and $36 \%$, respectively) with the soya diet. The quantities of enzymes in the gastric mucosa or the specific activity of pancreatic amylase were not affected, whereas that of lipase increased by $26 \%$. Total enzyme activities as well as units per $\mathrm{kg}$ live weight gave significant differences only for trypsin and chymotrypsin which were reduced by 43 and $38 \%$, respectively.

With the soya diet, fasting concentrations of gastric inhibitory peptide (GIP) and secretin in plasma samples were significantly lower ( 49 and $34 \%$, respectively). Values of GIP were also lower $(54 \%) 1 \mathrm{~h}$ after feeding. In contrast, postprandial values of cholecystokinin (CCK) were 1.4 times greater. No significant differences were found between the two diets for gastrin, vasoactive intestinal peptide (VIP), bovine pancreatic polypeptide (BPP), somatostatine and motilin. In general these observations could be explained, in part, by the more rapid passage of protein and fat from the abomasum to the duodenum following feeds containing soya concentrate. However, these differences in concentrations of gut hormones did not seem to be related to variations in the weights of gastric mucosa and pancreas or activities of pancreatic enzymes. 


\section{Introduction.}

The ingestion by preruminant calves of certain products derived from soyabean, such as soyabean flour, can result in reduced gastric and pancreatic secretion as well as a lowering of pancreatic protease activity in gut contents and digestive juice (see review of Toullec et al., 1983). This weakening of secretory function probably contributes to the survival of soya protein in the digestive tract. Some of these proteins, particularly glycinin and $\beta$-conglycinin, are thought to provoke adverse immune responses in the gut, leading to inflammatory tissue reactions and disorders in the digestive processes. In studies on calves fed heated soyabean flour these disorders included villous atrophy and oedema, abnormalities in the emptying of abomasal digesta and its rapid transit along the small intestine. Such animals also showed increased gut permeability to macromolecules and developed high titres of blood anti-soya antibodies ( $\lg G 1$ and sometimes $\lg E$ ) (Sissons, 1982 ; Sissons and Thurston, 1984).

The antigenic activity of soya protein can be eliminated by treatment with hot aqueous alcohol (Kilshaw and Sissons, 1979b ; Sissons et al., 1982). But when such products are fed to calves, the outflow of protein and fat to the duodenum tends to be somewhat quicker than that of milk products which are usually retained by the formation of a clot (Guilloteau et al., 1979). Furthermore, the secretion of chymosin continues to be reduced. Possible effects on the pancreas have not been studied. Similarly, apart from preliminary studies by Guilloteau et al. (1984, $1985,1986)$, little is known of the influence of dietary protein on hormonal regulation of the digestive function in calves.

In the present study of milk substitute diets for calves we have investigated the effects of replacing milk protein by concentrated soya protein treated with alcohol on the secretory activity of the abomasum and pancreas and on circulatory concentrations of several gut hormones. It was determined by in vitro immunochemical assay and by in vivo measurement of systemic antibody response that the soya product had no antigenic activity.

\section{Material and methods.}

Thirty-two male Friesian $\times$ Holstein calves were reared on a pre-experimental milk substitute diet until they were 8 weeks old. The protein source of this liquid diet was skim milk and whey powders. The calves were then divided into two groups (control and soya) of 16 animals each. The control group received a milk substitute until slaughter at 19 weeks of age (table 1); the protein was provided almost entirely by skim milk powder. The other group first received a milk substitute (soya 1 ; table 1 ) in which most of the protein was provided by skim milk and the rest by soya concentrate (Soycomil F, Unimills) and whey (49.9, 17.7 and $31.1 \%$, respectively). Four weeks later this diet was replaced by another milk substitute (soya 2 ; table 1 ) in which the protein was provided by whey and soya concentrate $(34.0$ and $63.5 \%$, respectively). The milk substitutes were fed by bucket twice daily, except on Sundays when only a morning feeding was 
given. The dry matter intake per feeding increased progressively from 910 to $1390 \mathrm{~g}$ from weeks 8 to 16 and then remained constant.

TABLE 1

Composition of the milk substitute diets.

\begin{tabular}{lccc}
\hline \multicolumn{1}{c}{ Diet } & Control & Soya 1 & Soya 2 \\
\hline g/100 g dry matter (1) : & & & \\
- protein & 24.3 & 24.7 & 26.7 \\
- fat & 19.9 & 23.2 & 25.9 \\
g/100 g total protein (1) : & & & \\
- skim milk powder & 92.7 & 49.9 & - \\
- soya concentrate (2) & - & 17.7 & 63.5 \\
- whey derivatives & 7.0 & 31.1 & 34.0 \\
- methionine & 0.2 & 0.3 & 0.4 \\
- lysine & - & 0.8 & 1.8 \\
\hline
\end{tabular}

(1) The different diets had similar contents of lysine and sulfur amino-acids, as well as digestible protein and energy per $\mathrm{kg}$.

(2) Containing $69 \mathrm{~g}$ protein $/ 100 \mathrm{~g}$ dry matter and prepared from dehulled soyabean by hexane extraction of oil and hot-aqueous ethanol extraction of sucrose and $\alpha$-galactosides.

Blood samples were taken from the jugular vein at 16 weeks of age (between 5 and $5 \mathrm{~h} 30$ after the morning feeding) and in the morning before the day of slaughter (before and $1 \mathrm{~h}$ after the morning feeding). At 16 weeks, the blood samples were heparinized and only taken from 18 calves chosen according to appetite : 10 calves (6 from the control group and 4 from the soya group) which consumed all their feeds on all of the previous days and 8 others from the soya group which refused a part of their ration. For the second collection, blood was taken from all the calves and the samples were heparinized and treated with aprotinin, a protease inhibitor. Titrations of IgG antibodies against soya protein were done on samples of blood plasma by passive haemagglutination of tanned sheep erythrocytes coated with a saline extract of heated soya flour (Kilshaw and Sissons, 1979a). Samples of the concentrated soya protein and of the powdered milk substitutes were assayed by haemagglutination inhibition for antigenic activity corresponding to the major soyabean globulins using tanned sheep erythrocytes coated with purified glycinin or $\beta$-conglycinin (Kilshaw and Sissons, 1979b). Concentrations of gut hormones were measured in the plasma of blood samples taken from calves on the morning before the day of slaughter. Measurements were done by radioimmunoassay using the double antibody technique. Details of the methods used have been reported by Chayvialle et al. (1978) for gastrin, Miazza et al. (1985) for bovine pancreatic polypeptide (BPP), cholecystokinin (CCK) and gastric inhibitory peptide (GIP), Pelletier et al. (1978) for secretin, Chayvialle et al. (1980) for somatostatin and vasoactive intestinal peptide (VIP) and Cuber et al. (1985) for motilin.

The abomasal mucosa and pancreas were removed from slaughtered calves and analysed for enzymes as described by Guilloteau et al. (1983). The quantities 
of chymosin and pepsin are given in $\mathrm{mg}$; the enzyme activities are expressed in $\mu \mathrm{mol}$ of acetyl-L-tyrosine-ethyl ester (ATEE) hydrolysed/min for trypsin, $\mu \mathrm{mol}$ of benzoyl-arginine-ethyl-ester (BAEE) hydrolysed/min for chymotrypsin, $\mu \mathrm{mol}$ fatty acid liberated $/ \mathrm{min}$ for lipase and by the number of terminal reducing groups after a 20-min hydrolysis of soluble starch for amylase.

Results of the two treatments were compared using Student's t-test, except for measurements of antibody and hormone concentrations which were evaluated by analysis of variance. In the latter case, the mean values were classed according to the Newman-Keuls' test.

\section{Results and Discussion.}

During the first 4 weeks of the experimental period, the soya-fed calves consumed more of their ration than the control calves $(0.2 \%$ refusal vs $1.3 \%)$; the difference was due to two calves of the control group refusing 7.2 and $9.2 \%$ of their ration, respectively. However, during the last 7 weeks of the trial the soya calves drank less than the control calves $(5.2 \%$ refusal vs $0.4 \%) ; 5$ of the soya group refused a large part of their ration ( $15.2 \%$ average $v s 5.1 \%$ refusal by only one control calf). Overall live weight gain (mean \pm SEM) was significantly lower $(\mathrm{P}<0.01)$ in soya calves $(1263 \pm 39 \mathrm{~g} / \mathrm{d})$ than in control calves $(1424 \pm 17 \mathrm{~g} / \mathrm{d}$ ). In agreement with results of Toullec and Patureau-Mirand (1979), the replacement of a major part of the milk proteins by soya concentrate and whey proteins resulted in a less favourable growth.

Circulatory antibodies against soya protein. - All of the plasma samples, including those of control group calves, gave low to intermediate titres of $\lg G$ antibodies against soya protein (table 2) compared with high titres ( $\log 2)$ of between 12 and 14 reported by Smith and Sissons (1975) for calves which received a diet containing heated soya flour. No significant difference was found between the control and soya groups. Also, there was no correlation between anti-soya IgG titres and the appetite of individual animals.

TABLE 2

Titres (log2 from a 1/10 initial dilution) of plasma anti-soya /gG (means and SEM)

\begin{tabular}{|c|c|c|c|}
\hline Age (weeks) & 16 & & \\
\hline Time of sampling & $\begin{array}{l}6 \text { th hour } \\
\text { after feeding }\end{array}$ & $\begin{array}{l}\text { before } \\
\text { feeding }\end{array}$ & $\begin{array}{c}1 \mathrm{~h} \\
\text { after feeding }\end{array}$ \\
\hline $\begin{array}{l}\text { Control diet: } \\
-6 \text { calves ingesting their entire ration }\left({ }^{a}\right) \\
- \text { all the calves }(16)\end{array}$ & $\begin{array}{c}4.7(0.5) \\
-\end{array}$ & $\begin{array}{l}5.7(0.5) \\
6.1(0.2)\end{array}$ & $\begin{array}{l}6.0(0.4)^{*} \\
6.3(0.2)\end{array}$ \\
\hline $\begin{array}{l}\text { Soya diet: } \\
-4 \text { calves ingesting their entire ration (9) } \\
-8 \text { calves refusing a part of their ration (i) } \\
- \text { all the calves (16) }\end{array}$ & $\begin{array}{l}4.3(0.3) \\
3.5(0.5)\end{array}$ & $\begin{array}{l}6.0(0.6) \\
6.6(0.2)^{* * *} \\
6.5(0.2)\end{array}$ & $\begin{array}{l}7.3(0.7) \\
6.6(0.3)^{* *} \\
6.6(0.3)\end{array}$ \\
\hline
\end{tabular}

(a): During the 15 th week

${ }^{* * *},{ }^{* *},{ }^{*}$ : Differed from 16 weeks $(P \leqslant 0.001,0.01$ and 0.05$)$. 
The reasons for the appearance of systemic anti-soya antibodies in the calves are unclear. In earlier studies, Kilshaw and Sissons (1979a) detected haemagglutinating antibodies showing titres of between 2 and 6 in 7 week-old milk-fed calves which had never received soya products in their diet; these authors concluded that such antibodies may have been of maternal origin. Dairy cows are commonly given rations containing heated soyabean meal, and this product might stimulate the immune system to produce the corresponding antibodies. In another study, significant quantities of anti-soya antibodies were detected in colostrum (Pedersen and Sissons, unpublished data). However, maternal antibodies which have been passively transferred to newborn calves usually decline during the first few weeks of life (Ishikawa and Konishi, 1982 ; Pedersen and Sissons, unpublished data). Considering that soya $\lg G$ antibodies were found in both groups of calves and that no antigenic activity was detected in the haemagglutination inhibition assay of soyabean concentrate or in samples of the control or in soya diets, it seems unlikely that these systemic antibodies were produced in response to the ingestion of any of the milk substitutes used in this study.

Titres of circulatory soya antibodies were slightly higher in both groups at 19 than at 16 weeks of age. No explanation was found for this increase. Blood samples taken at 19 weeks were treated with a protease inhibitor to preserve the gut hormones, and it may have also preserved the $\lg G$ antibodies. Further tests showed that the presence of such an inhibitor did not give a non-specific result in the passive haemagglutination assay. The values of samples taken at the end of the trial during fasting and shortly after the calves were fed indicated no change in the soya antibody levels as a result of feeding.

TABLE 3

Weight of the calves $(\mathrm{kg})$ and of their organs $(\mathrm{g})$, amounts of gastric enzymes $(\mathrm{mg} / \mathrm{g}$ abomasal mucosa), specific activities of pancreatic enzymes (units/g protein) and enzyme ratios (means and SEM).

\begin{tabular}{lcc}
\hline Diet & Control & \multicolumn{1}{c}{ Soya } \\
\hline Number of calves & $15^{a}$ & \multicolumn{1}{c}{16} \\
\hline Live weight & $199.1(2.0)$ & $185.0(2.8)^{* *}$ \\
Abomasum (fresh weight) & $309.5(11.1)$ & $273.6(9.4)^{* *}$ \\
- musculosa & $374.5(18.6)$ & $311.4(16.4)^{* *}$ \\
- mucosa & & \\
Pancreas & $137.6(5.2)$ & $109.6(4.2)^{* *}$ \\
- fresh weight & $18.6(0.9)$ & $15.7(0.6)^{*}$ \\
- total protein & $1.4(0.2)$ & $1.4(0.2)$ \\
\hline Chymosin & $1.4(0.1)$ & $1.3(0.1)$ \\
Pepsin & $14.5(0.9)$ & $10.2(0.7)^{* *}$ \\
Chymotrypsin & $1.1(0.0)$ & $0.7(0.0)^{* *}$ \\
Trypsin & $11.6(0.8)$ & $14.6(0.9)^{*}$ \\
Lipase & $96.8(5.9)$ & $95.2(4.5)$ \\
Amylase & $1.0(0.1)$ & $1.0(0.1)$ \\
Chymosin : pepsin & $13.0(0.6)$ & $15.6(1.3)$ \\
Chymotrypsin : trypsin & -1.2 & \\
\hline
\end{tabular}

a : One abomasum and one pancreas of the control group could not be assayed

**, ${ }^{*}$ : Differed from control values $(P \leqslant 0.001$ and 0.02$)$. 
Weight of the abomasum and pancreas. - The soya diet had a depressive effect on the weight of the gastric mucosa and the pancreas as well as on the activities of pancreatic proteases (table 3). When these values are expressed on a live weight basis, the effect of the soya diet on pancreas weight remains significantly different $(P<0.02)$ from that of the control diet $10.60 \pm 0.03$ and $0.69 \pm 0.03 \mathrm{~g} / \mathrm{kg}$, mean \pm SEM for the soya and control groups, respectively). But differences between these values were not significant for the abomasal mucosa $(1.65 \pm 0.09 \mathrm{~g} / \mathrm{kg}$ and $1.89 \pm 0.10 \mathrm{~g} / \mathrm{kg}$ for the soya and control groups, respectively) or for pancreatic protein $(86 \pm 43 \mathrm{mg} / \mathrm{kg}$ and $94 \pm 44 \mathrm{mg} / \mathrm{kg}$ for the soya and control groups, respectively). A reduction in pancreas size was also seen in calves given a milk substitute based on heated soyabean flour (Gorrill and Thomas, 1967).

Gastric enzymes. - There was no significant diet effect on the concentrations of chymosin or pepsin (table 3 ). This was also true of the total quantities of these proteases or after their expression on a live weight basis (fig. 1),

(A)
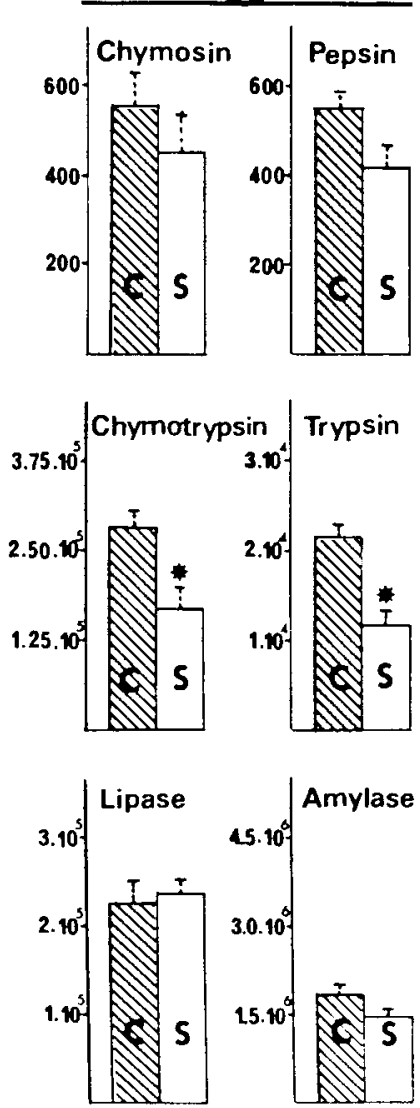

(B)
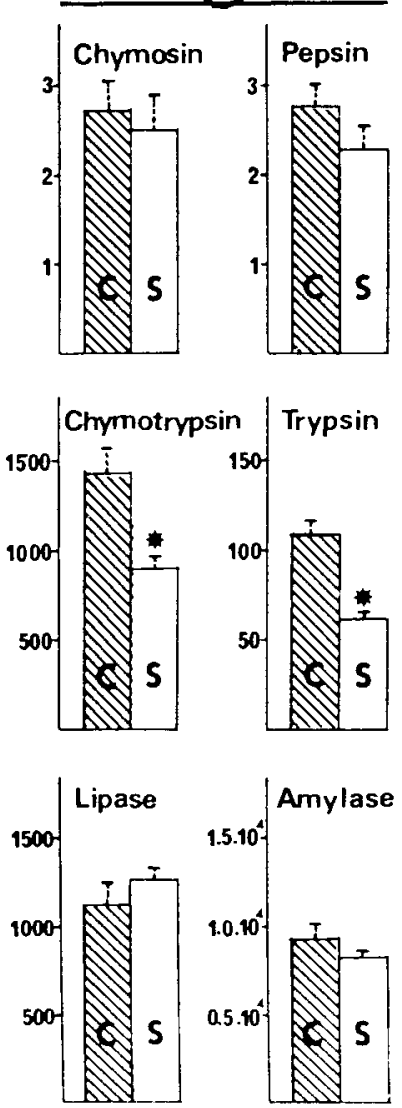

FIG. 1. - Amounts of gastric enzymes $(\mathrm{mg})$ and activities of pancreatic enzymes (units) in whole gland $(\mathrm{A})$ and per $\mathrm{kg}$ live weight $(\mathrm{B})$ (means and $\mathrm{SEM}$ ).

* : Differed from control values $(P \leq 0.001) ; C$ : Control group; $S$ : Soya group. 
although the average values tended to be lower for soya-fed calves. These results are similar to those we obtained for concentrations and quantities of enzymes collected daily from a gastric pouch in calves receiving a milk substitute containing fish protein (Guilloteau and Toullec, unpublished data). However, other workers (Williams, Roy and Gillies, 1976; Garnot et al., 1974, 1977) studying calves fed protein derived from soyabean, fish or whey, observed a decreased in chymosin and/or pepsin secretion and in their concentrations in abomasal digesta or mucosa. This, therefore, was not confirmed in the present study. The lack of agreement could be due to differences in methodology : we used rapidly chilled and frozen gastric mucosa whereas Garnot et al. (1974) used dried abomasal tissue.

Pancreatic enzymes. - Compared with the control diet, the soya diet had a depressive effect on the specific activity of trypsin and chymotrypsin (table 3 ). This was also true of measurements of total activity or that expressed per unit live weight (fig. 1); for example, the activity per $\mathrm{kg}$ live weight diminished significantly ( $P \leqslant 0.001 ; 43$ and $38 \%$, respectively). These results are in accord with those obtained by Gorrill and Thomas (1967), Gorrill et al. (1967) and Ternouth et al. (1975) in calves receiving a diet in which milk protein was replaced by that of heated soyabean flour. This reduction in the tissue activity of proteolytic enzymes could be due, in part, to the presence of residual protease inhibitors; the product specification of the manufacturer indicated that the soya concentrate used in the present work contained $4.6 \mathrm{mg}$ of anti-trypsin $/ \mathrm{g}$ of protein, which is equivalent to about $7 \%$ of that in unprocessed soyabean meal (Monti and Grillo, 1983). However, other factors are probably involved also because concentrated fish protein had similar effects on calf pancreatic proteases (Ternouth et al., 1975). Moreover, compared with milk protein, replacement protein is generally less sensitive to proteolytic enzymes (Jenkins, Madadevan and Emmons, 1980) and resides for a shorter time in the abomasum (Guilloteau et al., 1981).

Neither the specific activity of amylase nor that expressed in total or per unit live weight was significantly influenced by the diet (table 3 , fig. 1). This finding is contrary to an observation of Ternouth et al. (1975) indicating a decline in amylase secretion after milk protein was partially replaced by that of heated soyabean flour.

In contrast to results on proteolytic enzymes and amylase, the specific activity of lipase increased $(P<0.02)$ by $26 \%$ in calves given the soya diet. However, although the same trend applied to the values of total activity and activity per unit of live weight, the differences were not significant. Variation in lipase activity between the control and soya diets could be due to the higher amount of fat in the latter $(25.9$ vs $19.9 \%)$. Nevertheless, the nature of the protein may have had an effect since Ternouth et al. (1975) observed an increase in the lipase secretion of calves fed milk substitutes containg soyabean of fish protein.

Gastrointestinal hormones. - With the control diet, the postprandial plasma concentrations of gastrin, GIP and CCK were higher and that of secretin lower than the fasting values (table 4). No significant changes from fasting 
concentrations of BPP, VIP, somatostatin and motilin were observed after feeding. These results for gastrin, CCK, secretin, VIP and somatostatin are in general agreement with those of our previous work (Guilloteau et al., 1984, 1986a, b and unpublished data). Similarly, Bloom, Edwards and Hardy (1978) reported an increase in the plasma gastrin level in calves during the first two hours after milk ingestion. However, the present results for motilin and BPP are at variance with our earlier studies ; in two other experiments where we measured plasma motilin concentration, the values during fasting were higher than those found $1 \mathrm{~h}$ after feeding. Likewise, measurements of blood BPP concentrations, taken weekly from 1 to 13 weeks of age, were lower $1 \mathrm{~h}$ after feeding than the fasting levels. These variations in the results of different experiments done at different times may be due to differences in parasympathetic nervous system activity (Bloom, Edwards and Hardy, 1978).

TABLE 4

Plasma levels $(\mathrm{pg} / \mathrm{ml})$ of digestive hormones at 19 weeks of age (means and SEM).

\begin{tabular}{|c|c|c|c|c|}
\hline \multirow{2}{*}{$\begin{array}{l}\text { Diet } \\
\text { Number of calves }\end{array}$} & \multicolumn{2}{|c|}{ Control } & \multicolumn{2}{|c|}{ Soya } \\
\hline & \multicolumn{2}{|c|}{16} & \multicolumn{2}{|c|}{16} \\
\hline Time of sampling & before feeding & $1 \mathrm{~h}$ after feeding & before feeding & $1 \mathrm{~h}$ after feeding \\
\hline Gastrin (B) & $44(4)^{\mathrm{D}}$ & $113(13)^{\mathrm{D}}$ & $57(4)^{\mathrm{D}}$ & $120(8)^{\mathrm{D}}$ \\
\hline GIP $(A B)$ & $1051(110)^{\mathrm{cD}}$ & $2374(226)^{C D}$ & $534(53)^{\mathrm{cd}}$ & $1081(181)^{\mathrm{Cd}}$ \\
\hline Secretin $(A B)$ & $32(3)^{\mathrm{CD}}$ & $15(1)^{\mathrm{D}}$ & $21(2)^{\mathrm{Cd}}$ & $16(1)^{d}$ \\
\hline $\operatorname{CCK}(A B)$ & $45(7)^{\mathrm{D}}$ & $81(10)^{\mathrm{CO}}$ & $43(6)^{\mathrm{D}}$ & $194(25)^{C D}$ \\
\hline BPP (1) & $411(54)$ & $534(53)$ & $573(84)^{d}$ & $392(45)^{d}$ \\
\hline VIP (B) & $69(6)$ & $64(5)$ & $57(3)^{\mathrm{D}}$ & $88(4)^{D}$ \\
\hline Somatostatin & $38(3)$ & $39(3)$ & $34(5)$ & $27(4)$ \\
\hline Motilin & $61(6)$ & $63(14)$ & $53(4)$ & $51(4)$ \\
\hline
\end{tabular}
A, B : Significant effect of dietary protein $(A)$ and of feeding $(B)(P \leq 0.01)$.
$C, c:$ At a given sampling time, significant effect of dietary protein $(P \leq 0.01$ and 0.05$)$.
$D, d$ : For a given diet, significant effect of feeding $(P \leq 0.01$ and 0.05$)$.
(1) : Significant effect of feeding for the soya diet according to paired t-test.

Variations in plasma levels of gastrin, GIP, secretin, motilin and somatostatin in response to the soya diet were closely similar to those found with the control diet. The postprandial increase of CCK concentration was much greater (4.2fold). In contrast, a postprandial increase $(1.5$-fold) was observed for VIP and a decrease $(0.7$-fold) for BPP with the soya diet, although no such changes were seen with the control diet. Fasting concentrations of GIP and secretin were lower (2.0 and 1.5 -fold, respectively) with the soya diet. One hour after feeding, the GIP level was 2.2-fold lower and that of CCK 2.4-fold higher with the soya diet. In general, the results of gastrin, secretin, CCK and BPP agree with those found in earlier experiments with a milk substitute in which partially hydrolysed fish protein replaced casein (Guilloteau et al., 1984, 1985, 1986).

Coagulation does not occur in the abomasum when alternative proteins replace milk protein in liquid feeds for calves, and the passage of protein and fat to the small intestine is more rapid (Toullec et al., 1983). This change in gastric 
outflow probably contributes to modify the secretory patterns of different hormones. For example, in the present experiment, an increase in the amounts of protein and fat entering the duodenum after feeding the soya 2 diet would have favoured an elevation in plasma CCK (Rehfeld, 1980). The difference between plasma GIP values with the control and soya diets may be related not only to differences in gastric fat emptying but also to variations in glucose absorption. Although earlier work in calves fed different milk substitutes showed that abomasal patterns of lactose emptying were not much affected by the nature of the protein (Guilloteau et al., 1979), the soya 2 diet in the present study contained only $70 \%$ of the amount of lactose in the control diet. Thus, a reduction in the amounts of lactose entering the duodenum, and consequently the reduced amounts of glucose absorbed, could have resulted in a weaker concentration of blood GIP (Ebert and Creutzfeldt, 1980). Before feeding, the abomasum of the calves receiving the soya diet was more empty than that of the control animals. This might result in less acid chyme flowing to the duodenum in the soya-fed calves; this, in turn, would lead to a lower secretin release (Chey et al., 1981).

Present results with the soya diet do not show a clear relationship between modifications in the weight of the digestive organs and the quantities of enzymes on one hand and variations in circulatory hormone levels on the other. Both gastrin and CCK have trophic effects on the pancreas (Balas, Senegas-Balas and Bastie, 1981) but, since the soya diet did not modify the gastrin level and increased the postprandial CCK level, the decrease in pancreas weight was presumably due to some other mechanism not identified in this study. Similarly, the decrease in pancreatic protease activity in soya-fed calves is not consistent with the increase in postprandial CCK levels (Davicco, 1978). Furthermore, the tendency for a decrease in pepsin levels, albeit non-significant (fig. 1), is not in accord with the decline in circulatory GIP levels. However, the inhibitory effect of this peptide remains uncertain (Ebert and Creutzfeldt, 1980). At the same time, the concentration of secretin, which is thought to have stimulatory effects on pepsin secretion (McLeay and Bell, 1981), also declined compared with its concentrations in the controls. Kinetic studies of gastric and pancreatic secretions together with simultaneous measurement of circulatory hormone levels would perhaps improve our understanding of these relationships.

In conclusion, the replacement of milk protein by that of soyabean concentrate and whey did not appreciably modify the amounts of enzymes present in the abomasal mucosa but did lead to reduced trypsin and chymotrypsin activities in the pancreas. The plasma level of several digestive hormones (GIP, secretin and (CK) was also affected. However, these variations seemed to be related more to changes in gastric emptying than to alterations in the enzyme activities. Finally, the blood of the dairy cow calf commonly possesses moderate concentrations of anti-soya antibodies which could be of maternal origin. 
Acknowledgements. - Thanks are due to P. Martin for determining the correspondance between coagulation activity and amounts of abomasal enzymes and to Unimills (Dammtorwall 15.2000 Hamburg, FRG) for financial support.

Résumé. Effet de la protéine de soja sur les enzymes digestives, les niveaux plasmatiques des hormones gastro-intestinales et les anticorps anti-soja chez le veau préruminant.

Le but de ce travail est d'étudier l'effet d'un concentrat de soja préparé par extraction hydroalcoolique à chaud, de manière à éliminer le saccharose et les alpha-galactosides et à inactiver les facteurs antigéniques, sur la caillette, le pancréas et les taux plasmatiques de 8 hormones digestives. Deux laits de remplacement, dont les protéines sont apportées en majeure partie par de la poudre de lait écrémé ou par le concentrat de soja, sont distribués chacun à 16 veaux entre les âges de 12 et 19 semaines.

Les concentrations plasmatiques d'lgG anti-soja sont élevées mais identiques quel que soit le régime. Il semble donc invraisemblable que la présence de ces anticorps soit reliée spécifiquement à l'ingestion de soja.

A l'abattage, les poids de muqueuse gastrique, de pancréas frais et de protéines pancréatiques, ainsi que les activités spécifiques de la trypsine et de la chymotrypsine sont significativement plus faibles avec le régime soja (respectivement de 17, 20, 16, 30 et $36 \%$. En revanche, les quantités d'enzymes gastriques par $\mathrm{g}$ de muqueuse et l'activité spécifique de l'amylase pancréatique ne sont pas modifiées tandis que celle de la lipase est accrue de $26 \%$. Lorsque les résultats d'enzymes sont exprimés en activité totale ou par unité de poids vif, seules les valeurs concernant la trypsine et la chymotrypsine demeurent significativement affectées par le régime (activités/ $\mathrm{kg}$ de poids vif réduites de 43 et $38 \%$ avec le régime soja).

Avec le régime soja, les concentrations plasmatiques préprandiales sont significativement plus faibles pour le GIP et la sécrétine (respectivement de 49 et $34 \%$ ) ; il en est de même $1 \mathrm{~h}$ après le repas pour le GIP (de $54 \%$ ). Seule la CCK présente une valeur plus élevée avec le régime soja (de $140 \% 1 \mathrm{~h}$ après le repas). Aucune différence significative n'est observée pour la gastrine, le VIP, le BPP, la somatostatine et la motiline. Ces modifications peuvent s'expliquer en partie par l'évacuation gastrique plus rapide des protéines et des lipides avec le régime soja ; en revanche, elles ne semblent pas pouvoir être reliées aux variations concernant les poids de muqueuse gastrique et de pancréas et les activités enzymatiques du pancréas.

\section{Références}

BALAS D., Senegas-balas F., BASTIE M. J., 1981. Trophicité des muqueuses digestives. Reprod. Nutr. Dévelop., 21, 783-803.

BLOOM S. R., EDWARDS A. V., HARDY R. M., 1978. The role of the autonomic nervous system in the control of pancreatic endocrine responses to milk ingestion in the calf. $J$. Physiol, 280, 37-53.

CHAYVIALLE J. A., DESCOS F., MARTIN A., BARBE C., PARTENSKY C., 1978. Somatostatin in mucosa of stomach and duodenum in gastrointestinal desease. Gastroenterology, 75, 13-19.

CHAYVIALLE J. A., MIYATA M., RAYFORD P. L., THOMPSON J. C., 1980. Effect of test meal, intragastric nutrients and intraduodenal bile on plasma concentrations of immunoreactive somatostatin and vasoactive intestinal peptide in dogs. Gastroenterology, 79, 844-852.

CHEY W. Y., CHANG T. M., LEE K. Y., ROMINGER J., RHODES R. A., YOU C. H., 1981. Secretin physiology, 213-219. In BLOOM S. R., POLAK J. M., Gut hormones, Churchill Livingstone, Edinburgh.

CUBER J. C., BERNARD C., LAPLACE J. P., CHAYVIALLE J. A., 1985. Comparative assessment of secretin and motilin responses to graded duodenal acidification in anesthetised pigs. Digestion, 31, sous presse.

DAVICCO M. J., 1978. Régulation du pancréas exocrine chez le veau. Th. Univ. Clermont II, $\mathrm{n}^{\circ} 542,100 \mathrm{pp}$. 
EBERT R., CREUTZFELDT W., 1980. Gastric inhibitory polypeptide, 679-698. In CREUTZFELDT W., Clinics in gastroenterology, 9, Saunders $\mathrm{Co}$. London.

GARNOT P., THAPON J. L., MATHIEU C. M., MAUBOIS J. L., RIBADEAU DUMAS B., 1974. Influence of dietary proteins on rennin and pepsin content of preruminant calf vell. J. Dairy Res., 41, 19-23.

GARNOT P., TOULLEC R., THAPON J. L., MARTIN P., MINH-THU HOANG, MATHIEU C. M., RIBADEAU DUMAS B., 1977. Influence of age, dietary protein and weaning on calf abomasal enzymatic secretion. J. Dairy Res., 44, 9-23.

GORRILL A. D. L., THOMAS J. W., 1967. Body weight changes, pancreas size and enzyme activity, and proteolytic enzyme activity and protein digestion in intestinal contents from fed soyabean and milk protein diets. J. Nutr., 92, 215-223.

GORRILL A. D. L., THOMAS J. W., STEWART W. E., MORRILL J. L., 1967. Exocrine pancreatic secretion by calves fed soybean and milk protein diets. J. Nutr., 92, 86-92.

GUILLOTEAU P., CHAYVIALLE J. A., TOULLEC R., GRONGNET J. F., DARDILLAT C., 1984. Early life pattern of plasma secretin level in calves. Can. J. anim. Sci, 64 (suppl.), 100-101.

GUILLOTEAU P., CHAYVIALLE J. A., TOULLEC R., GRONGNET J. F., DARDILLAT C., 1985. Evolution du taux circulant de gastrine chez le veau. Reprod. Nutr. Dévelop., 25, 780.

GUILLOTEAU P., CHAYVIALLE J. A., TOULLEC R., GRONGNET J. F., DARDillat C., 1986. Evolution du taux plasmatique de CCK chez le veau avec l'âge et le régime alimentaire. Reprod. Nutr. Dévelop., 26, 377.

GUILLOTEAU P., CORRING T., GARNOT P., MARTIN P., TOULLEC R., DURAND G., 1983. Effects of age and weaning on enzyme activities of abomasum and pancreas of the lamb. $J$. Dairy Sci, 66, 2373-2385.

GUILLOTEAU P., TOULLEC R., PATUREAU-MIRAND P., PRUGNAUD J., 1981. Importance of the abomasum in the preruminant calf. Reprod. Nutr. Dévelop., 21, 885-899.

GUILLOTEAU P., TOULLEC R., SAUVANT D., PARUELLE J. L., 1979. Utilisation des protéines par le veau préruminant à l'engrais. VII. Influence du remplacement des protéines du lait par celles du soja ou de la féverole sur l'évacuation gastrique. Ann. Zootech., 28, 1-17.

ISHIKAWA H., KONISHI T., 1982. Changes in serum immunoglobulin concentrations of young calves. Jap. J. vet. Sci., 44, 555-563.

JENKINS K. J., MAHADEVAN S., EMMONS D. B., 1980. Susceptibility of proteins used in calf milk replacers to hydrolysis by various proteolytic enzymes. Can. J. anim. Sci., 60, 907914.

KILSHAW P. J., SISSONS J. W., 1979a. Gastrointestinal allergy to soyabean protein in preruminant calves. Antibody production and digestive disturbances in calves fed heated soyabean flour. Res. vet. Sci, 27, 361-365.

KILSHAW P. J., SISSONS J. W., 1979b. Gastrointestinal allergy to soyabean protein in preruminant calves. Allergenic constituents of soyabean products. Res. vet. Sci, 27, 366-371.

McLEAY L. M., BELL F. R., 1981. Effect of cholecystokinin, secretin, glucagon and insulin on gastric emptying and acid secretion in the calf. Am. J. vet. Res., 41, 1590-1594.

MIAZZA B., PALMA R., LACHANCE J. R., CHAYVIALLE J. A., JAUNARD P., MODIGLIANI R., 1985. Jejunal secretory effect of intraduodenal food in humans. A comparison of mixed nutrients, proteins, lipids and carbohydrates. Gastroenterology, 88, 1215-1222.

MONTI L. M., GRILLO S., 1983. Legume seed improvement for protein content and quality, 49-62. In BODWELL C. E., PETIT L., Plant proteins for human food, Martinus Nijhoff/DR W. Junk, the Hague.

PELLETIER M. J., CHAYVIALLE J. A., MINAIRE Y., 1978. Uneven and transient secretin release after a liquid test-meal. Gastroenterology, 75, 1124-1132.

REHFELD J. S., 1980. Cholecystokinin, 593-607. In CREUTZFELDT W., Clinics in gastroenterology, 9. Saunders Co. London.

SMITH R. H., SISSONS J. W., 1975. Effects of different feeds, including those containing soya-bean products, on the passage of digesta, from the abomasum of the preruminant calf. Br. J. Nutr., 33, 329-349.

SISSONS J.W., 1982. Effects of soya-bean products on digestive processes in the gastrointestinal tract of preruminant calves. Proc. Nutr. Soc., 41, 53-61.

SISSONS J. W., NYRUP A., KILSHAW P. J., SMITH R. H., 1982. Ethanol denaturation of soya bean protein antigens. J. Sci. Food Agric., 33, 706-710. 
SISSONS J. W., THURSTON S. M., 1984. Survival of dietary antigens in the digestive tract of calves intolerant to soyabean products. Res. vet. Sci, 37, 242-246.

TERNOUTH J. H., ROY J. H. B., THOMPSON S. Y., TOOTHILL J., GILLIES C. M., EDWARDSWEBB J. D., 1975. Concurrent studies of the flow of digesta in the duodenum and of exocrine pancreatic secretion of calves. 3. Further studies on the addition of fat to skim milk and the use of non-milk proteins in milk-substitute diets. Br. J. Nutr., 33, 181-196.

TOULLEC R., GUILLOTEAU P., PATUREAU-MIRAND P., SISSONS J. W., 1983. Digestion and absorption of protein in the preruminant, 245-261. In ARNAL M., PION R., BONIN D., Protein metabolism and nutrition, I, Ed. I.N.R.A. Publ., Versailles.

TOULLEC R., PATUREAU-MIRAND P., 1979. Influence du procédé d'hydrolyse des protéines de poisson sur leur utilisation par le veau de boucherie. Comparaison avec les protéines de lait et celles de soja. Ann. Zootech., 28, 407-422.

WILLIAMS V. J., ROY J. H. B., GILLIES C. M., 1976. Milk substitute diet composition and abomasal secretion in the calf. Br. J. Nutr., 36, 317-335. 